Historic, Archive Document

Do not assume content reflects current scientific knowledge, policies, or practices. 



\section{Pencillaria Zeaoides} IOO DAYS FROM SEED-14 FEET HIGH

\section{IOO DAYS FROM SEED $I 4$ FEET HIOH}
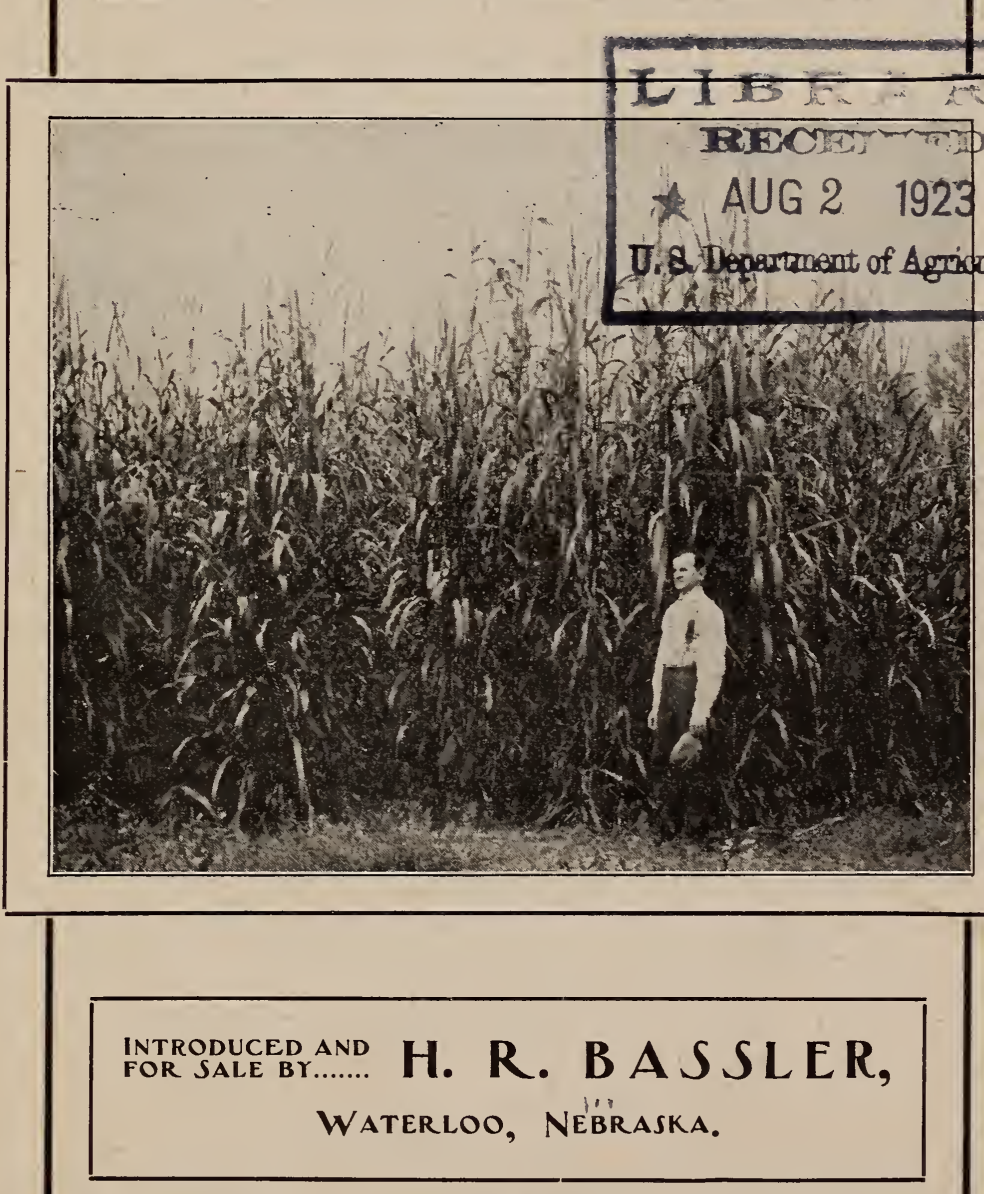


\section{Pencillaria Zeaoides}

(MAND'S WONDER FORAGE PLANT.)

7 HE most productive hay or fodder plant in cultivation.

This plant is worthy the careful investigation of every progressive Farmer, Dairyman, Stockman and Poultry Raiser in the country.

\section{HISTORY.}

This plant is a native of Central America and the tropics. A sea-captain, engaged in the Atlantic coasting trade, saw it growing in Honduras and was astonished at its luxurience and enormous growth. Securing some of the seed he brought it home and parcelled it out among some friends. Those who planted at the proper season had the most satisfactory results. Since then it has been tried in every section of this country with such uniformly good results that it can safely be ranked as the most valuable plant for fodder, hay or ensilage that can be cultivated.

\section{DESCRIPTION.}

It is an annual, having an enormous growth of broad, dark, green leaves, very much resembling Indian corn, and equals in nutritive value those wellknown forage plants: sorghum, Kaffir corn, etc., while far surpassing them in productiveness.

If permitted to fully develop it will attain a height of from 12 to 14 feet, bearing numerous heads completely covered with seeds.

It is closely allied to the well-known Pearl Millet and resembles it very much in appearance and manner of growth, but in all other respects is far superior; not being restricted in latitude, and growing wherever corn can be grown.

H. R. BASSLER.

West End Jersey Herd,

Dear Sir: I have not given the new forage plant as thorough a trial as I had hoped to, but must say it is certainly a very productive plant.

My horses relish it very much. Will try more of it another year. 


\section{PENCILLARIA ZEAOIDES}

AS A HAY PLANT.

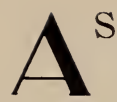

a rapid-growing hay plant it is unequalled; each plant throws out numerous stools, similar in that respect to wheat, and grows so rapidly that in from five to six weeks it is ready to be mowed. This operation can be repeated from 3 to 5 times during the season, and will yield several tons of hay to each cutting.

For hay purposes, it should be very thinly sown in drills, 12 to 18 inches apart, dropping a seed every 6 or 8 inches. If sown broadcast sow one pound of seed per acre, or as thin as you sow turnip seed.

\section{PENCILLARIA ZEAOIDES}

AS A FODDER PLANT.

COR this purpose it should be sown in drills, 3 or $3 \mathrm{t} / 2$ feet apart, thinning out to stand 18 inches apart in the drill. When high enough cultivate the field thoroughly, as this may be the only opportunity; the growth soon becoming so dense, that a cultivator could not be used a second time.

Cut it when in blossom, it is then 5 or 6 feet high, and remove the fodder; it will then make a second growth before the growing season is over and, altogether, will give the heaviest yield of fodder ever taken from the same area.

For feeding, it is equal to any fodder, and is relished by all kinds of stock, used either green or cured.

H. R. BASSLER.

Lebanon, Tenn., Oct. 5, 1900.

Dear Sir: I received the package of Pencillaria Zeaoides so late that it was not planted until the beginning of July. After it was planted we had considerable of a drouth. but with all this I can say that it is, decidedly, a superior forage plant. It is now in full head, and I trust that it will ripen the seed so that I can give it a fair test next year. 


\section{PENCILLARIA ZEAOIDES}

AS A GREEN FOOD.

$\mathrm{T}$ is a most nutritious food and is relished by all stock-horses, cattle or hogs, being in fact all they require for a perfect food. An acre of Mand's Wonder Forage Plant, if cut and carried to the stock, will support 4 cows, and other stock in proportion, from the time it is 30 inches high until the end of the season.

Used in this way, it can be grown as far north as Canada or the New England states, making its growth, greater or less, according to the length of the season, but wherever grown it will be found to yield heavier than any other plant in that locality.

\section{PENCILLARIA ZEAOIDES}

AS A SEED PRODUCER.

W

/HEN grown for its seed it must have ample space to grow in, and each plant should stand 2 to 3 feet apart in the rows, which should be 3 to $3 \frac{1}{2}$ feet apart. Cultivate them twice, if possible, and by the time the plants are three months old, the sight will astonish the beholder. With us they will be from 12 to 14 feet high (see cover page) and average 40 stalks to each plant, and 20 seed heads, which are from 12 to 24 inches long and covered with seeds. Beside giving a very heavy crop of fodder, it will yield from 2500 to 3000 pounds seed per acre. The seed is unequalled for poultry food and will ripen in any latitude that will ripen corn.

H. R. BASSLER,

Table Mountain Ranch,

Murphey's, Calaveras Co., Cal., Sept. 12, 1900.

Dear Sir: Mand's Wonder Forage Plant was sent for too late to have the best results, but we are very much pleased with it. Next year we shall be able to cut it at least 4 times by planting in March. Hogs and cattle do well on it and we can recommend it.

Respectfully yours,

E. ADAMS, PROP. 


\section{SOME DONT'S.}

Don't fail to procure seed of Mand's Wonder Forage Plant at once, if you are in any way interested in stock.

Don't fail to plant some this year.

Don't plant it until the ground is warm enough for cucumber vines.

Don't sow it too thick, or in rows too close together.

Don't use more than a pound to the acre if sown broadcast.

Dont sow it on poor or thin soil, and expect wonders. Don't throw this aside if not interested, but favor me by handing it to some one who is.

Don't hesitate to send me the names of such persons whom you think might be interested.

\section{PENCILLARIA ZEAOIDES}

Will be offered by the seed trade generally at the price of 25 cents per oz. packet, which will be sufficient to seed about 2000 feet of drill. If your seedsman does not offer it, I will supply it at the following prices:

One packet, containing one ounce, . _ . . . . . . . . \$.25 Three packets, Six packets, Per lb., in bulk,

Remit by Money Order or Stamps to

\section{H. R. BASSLER, INTROdUCER, Waterloo, Neb.}

WATERLOO, NEB., is the shipping point of the most extensive vine seed and seed corn growing territnry in the world, and I am in the position to furnish carefully grown and specially prepared Sweet Corns and Field Corns of the best quality and purity.

CORRESPONDENCE SOLICITED

H. R. BASSLER :

Mineral Springs, Ark., Oct. 3, 1900.

I am very favorably impressed with Mand's Wonder Forage Plant. It was planted rather late. but grew to the height of tifteen feet and produced more fodder than any plant grown here. My neighbors as well as myself expect to sow a large area next year. I cut part of the crop for the stock and find that they love it.

I will gladly do

$\mathrm{n}$ to help vou introduce the seed.

Yours truly,

P. B. JOHNSON. 


\section{The MAGICAL "ELI". $\therefore$ SPRAYER.}

THE ELI-SPRAYER is the most

valuable horticultural requisite introduced for many years, and is destined to work a revolution in garden experience.

It is necessary alike to the FARMER, GARDENER, ORCHARDIST, Smali, FrUit GROWER, TOBACCO RAISER, FLORIST, POULTRY KEEPER, OR DAIRYMAN. : :

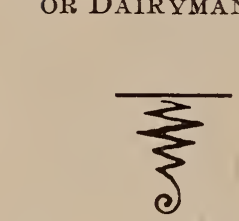


WILLIONS of dollars are annually lost to the agricultural community through the depredations of insects. Much of this loss can be avoided by judicious spraying. Of the many on the market, the best of the low-priced sprayers is

\section{The

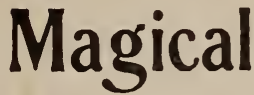

It is very compact and substantial. Cannot injure it by dropping it.

Can be hung up when not in use.

So simple that anyone can repair.

Will last many seasons with suitable care.

Always ready for use.

It is the simplest, cheapest and lightest Sprayer on the market.

It is the most effective and most economical one.

It consumes the least material for the best results.

Works freely with little labor.

It will save its cost many times during the season.

Weighs only two pounds when fully charged and ready for use.

If you use it once you will never want to be without it.

With the ELI-Sprayer, one pint of preparation will do the work of twelve gallons.

By using the ELI-Sprayer you adopt the easiest way of doing a disagreeable but necessary job.

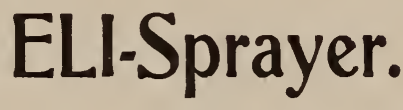

IT CAN BE USED FOR

Spraying Insecticides of any sort wherever insects can be located, in house or barn. plant or animal.

For destroying roaches, bed bugs or other vermin.

For disinfecting sick rooms or other apartments.

For applying fungicides.

Twelve ounces Paris Green and six quarts of water will effectually spray an acre.

Less danger of injuring plants than by any other method.

The poisons are sent out with such force that it reaches every part of the plant with one movement.

It can not poison stock if carelessly left around.

You can save your crops by using The Magical ELI-Sprayer.

You can relieve your stock by spraying them at intervals with vermin destroyers.

The ELI-Sprayer is the cheapest, simplest and most effective distributer that has been devised. It is also very economical, using the smallest quantity of poison with the most effective results, and saves its cost several times during the season in poisons alone.

The ELI-Sprayer is light and convenient to handle; labor saving in the best sense of the word; always ready for use; easy to keep in order, and is put together so carefully that it is almost impossible to accidently disarrange the mechanical adjustment.

By using the proper poisons or remedies in the ELI-Sprayer a magical effect is produced wherever insects can be located, either on plants or animals.

The ELI-Sprayer has demonstrated its practical value wherever it has been used, and many buyers have said that they would not take $\$ 10.00$ for their ELI-Sprayer if they could not replace it, and they continue enthusiastic in its praise.

This method of applying poisons is Sure Death to bugs and insect life of any kind; also lice and fleas on animals and poultry.

Delivered to any part of the U.S. for $\$ 1,00$ each. 


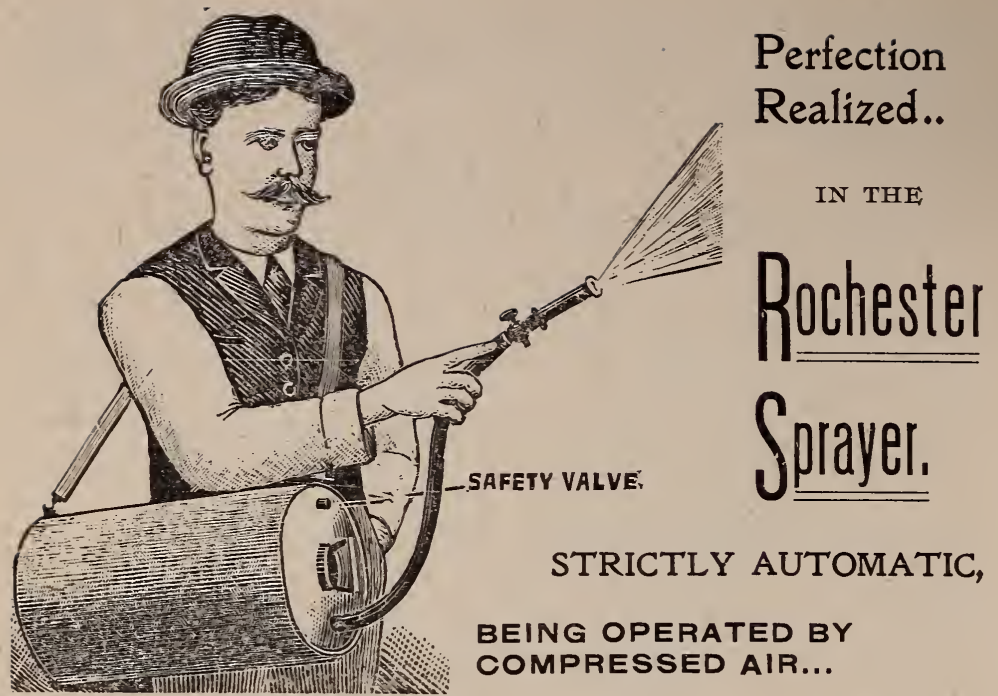

$7 \mathrm{HE}$ Rochester is the very best sprayer that can be pro1 cured, and is so durable that it will last a life-time.

It is very substantially made, of steel or brass, and will throw a solid stream or a fine misty spray by properly arranging the stop-cock.

Its uses are numerous-Besides doing all the work credited to the Eli-Sprayer (page 7) it can be used for spraying trees, washing buggies, windows, watering plants, subduing small fires, etc., etc.

NO BACK-ACHE FROM PUMPING OR STOOPING.

PRICES:

Steel, with hose, safety valve and nozzle......................\$5.00 Brass or Copper (best for arsenical solution) ........................ 50

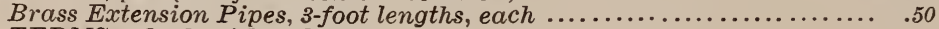

TERMS.-Cash with order.

NOTE.-If you desire to try a sprayer before purchasing, send me $\$ 1.50$ as a guaranty of good faith, to secure me in the cost of shipping, and I will send a Sprayer on approval; the balance to be paid to the Express Agent, if result proves satisfactory.

\section{AdDRESS H. R. BASSLER,}

Wholesale and Retail Agent, .....WATERLOO, NEBRASKA. 